Agrovoc descriptors: rosa, anthocyanins, phenolic compounds, aromatic compounds, soil ph, soil chemicophysical properties, flowers, chemical composition, proximate composition, soil fertility

Agris category code: F60, P35

\title{
Substrate pH level effects on anthocyanins and selected phenolics in Rosa $\times$ hybrida L. 'KORcrisett'
}

\author{
Valentina SCHMITZER ${ }^{\mathrm{a}}$, Franci ŠTAMPAR ${ }^{\mathrm{b}}$
}

Received October 6, 2009; accepted February 24, 2010.

Delo je prispelo 6. oktobra 2009; sprejeto 24. februarja, 2010.

\begin{abstract}
The effect of substrate $\mathrm{pH}$ level $(4.7,3.3$ and 7.3) on the anthocyanin, quercetin compounds, catechin and phenolic acids concentrations in petals of Rosa $\times$ hybrida L. 'KORcrisett' and on the number of flowers per plant was investigated. The phenolic profiles of this plant were established for the first time by the use of HPLC/MS. Plants potted in a substrate with $\mathrm{pH} 4.7$ developed significantly more flowers compared to those planted in an acidic (3.3) and alkaline (7.3) $\mathrm{pH}$ levels. However, the concentration of anthocyanins, quercetin compounds, catechin and phenolic acids was always lowest in the petals of 'KORcrisett' rose plants potted in $\mathrm{pH}$ level 4.7. Compared to the first sampling, a significant increase in the concentration of major and total anthocyanins and quercetin compounds was measured in the petals of plants potted in $\mathrm{pH}$ level 3.3 and 7.3, but not in the plants potted in $\mathrm{pH}$ level 4.7, respectfully.
\end{abstract}

Key words: rose, $\mathrm{pH}$, substrate, anthocyanins, phenolic compounds

\section{IZVLEČEK}

\section{VPLIV pH SUBSTRATA NA ANTOCIANE IN FENOLE PRI Rosa $\times$ hybrida L. 'KORcrisett'}

Preučevali smo vpliv $\mathrm{pH}$ substrata $(4,7,3,3$ in 7,3$)$ na koncentracije antocianov, kvercetinov, katehina in fenolnih kislin v petalih Rosa $\times$ hybrida L. 'KORcrisett' ter spremljali število cvetov na posamezno rastlino. Sestava in koncentracija fenolnih spojin je bila pri tej rastlini prvič določena s pomočjo HPLC/MS tehnike. Rastline, ki so bile posajene $\mathrm{v}$ substrat $\mathrm{s} \mathrm{pH} 4,7$, so razvile statistično značilno več cvetov, kot rastline, posajene v kisel $(3,3)$ oziroma bazičen $(7,3) \mathrm{pH}$, vendar pa so bile koncentracije antocianov, kvercetinov, katehina in fenolnih kislin $\mathrm{v}$ pH 4,7 najnižje. V primerjavi s prvim vzorčenjem, je koncentracija prevladujočih in skupnih antocianov $\mathrm{v}$ petalih močno narasla pri rastlinah, ki so bile posajene $\mathrm{v}$ substrat $\mathrm{s} \mathrm{pH}$ 3,3 in 7,3 . Podobnega trenda nismo opazili pri rastlinah, posajenih $\mathrm{v} \mathrm{pH} 4,7$.

Ključne besede: vrtnica, $\mathrm{pH}$, substrat, antociani, fenolne spojine

\section{INTRODUCTION}

Roses are one of the most important, diverse and widely planted ornamentals with over 150 species and more than 20.000 cultivars (Cai et al., 2005) with color specter ranging from subtle whites, yellows and pinks to intense purple, orange and red tones. The color of various plant tissues, such as flower petals (Mikanagi et al., 1995) and leaves (Schmitzer et al., 2009a), can be attributed to anthocyanins and other phenolics, for example quercetins, acting as copigments (Eugster and Markifischer, 1991).

\footnotetext{
a) University of Ljubljana, Biotechnical Faculty., Department of Agronomy, Jamnikarjeva 101, SI-1000 Ljubljana, Slovenia, univ. dipl. inž. kraj. arhit., dipl. inž. agr., e-mail: valentina.schmitzer@bf.uni-lj.si

b) ibid, prof., Ph.D.
} 
Flower pigments accumulate in the epidermal cell vacuoles (Hughes et al., 2007) and their concentration, intensity and hue depends on both internal, such as microenvironment conditions in the vacuoles and developmental stage (Schmitzer et al., 2009b), and external factors. Among the latter light (Cominelli et al., 2007), temperature (Dela et al., 2003), nutrient deficiency (Juszczuk et al., 2004) and substrate pH (Smith et al., 2004a) has been reported to alter anthocyanin and carotenoid concentration in various plant tissues. Root substrate $\mathrm{pH}$ also affects nutrient solubility (Smith et al., 2004b; Papafotiou et al., 2007) and influences root formation (Harbage et al., 1998) with a direct impact on overall status of the plant. In roses, root growth was inhibited when plants were exposed to either $\mathrm{pH} 8$ or $\mathrm{pH} 4$ in comparison with plants grown in $\mathrm{pH}$ 6. Additionally, plant growth, leaf size and chlorophyll levels were not affected in plants at
$\mathrm{pH} 4$, while all these variables were reduced at $\mathrm{pH} 8$ in comparison with plants grown at $\mathrm{pH} 6$ (Zieslin and Snir, 1989).

We hypothetisized that the concentration of phenolic compounds (anthocyanins, quercetin compounds, catechin and phenolic acids) in petals of the miniature rose 'KORcrisett' differs according to substrate $\mathrm{pH}$ levels. The objective of our study was thus to determine the effects of the substrate $\mathrm{pH}$ level on the concentration of secondary metabolites in rose petals, important from the commercial aspect of miniature rose production as well as from the viewpoint of plants response to external stress. As plants grown outside their acceptable $\mathrm{pH}$ range show signs of chlorosis and general decline (Smith et al., 2004 a) a reduction in the number of flowers can also be expected in miniature roses potted in acidic or alkaline $\mathrm{pH}$ levels.

\section{MATERIALS AND METHODS}

\subsection{Plant material and growth conditions}

Rosa $\times$ hybrida L. 'KORcrisett' plants were planted in 1.31 plastic pots ( $14 \mathrm{~cm}$ in diameter), containing a growth medium, prepared by mixing $80 \%$ of black peat and $20 \%$ of mineral component (sand). The substrate $\mathrm{pH}$ levels were modified by liming with calcium carbonate; the amount of lime was calculated on the base of a $\mathrm{pH}$ curve and three different $\mathrm{pH}$ levels were set up; treatment $\mathrm{A}$ with $\mathrm{pH}$ level 3.3, treatment $\mathrm{B}$ with $\mathrm{pH}$ level 4.7 and treatment $\mathrm{C}$ with $\mathrm{pH}$ level 7.3. For each treatment 15 plants were planted; the experiment was a randomized block design on a single bench. Plants were grown from the beginning of August to September 2008 in a controlled environment glass greenhouse at $27 / 22{ }^{\circ} \mathrm{C}$ (day/night) equipped with a cooling system under natural photoperiod. The greenhouse environmental control system was set to start cooling at $27{ }^{\circ} \mathrm{C}$. Relative humidity ranged from $75-85 \%$. Plants were irrigated daily, using a flood irrigation system with 4 minutes water $\left(18^{\circ} \mathrm{C}\right)$ supply. The number of flowers per plant (buds to senescent flowers) was counted at the beginning of the experiment on 12. Aug. 2008 (day 0) and on 8. Sept. (day 28). At the same time petals (flower developmental stage 3; Muller et al., 1998) for the extraction of phenolics were collected and immediately frozen in liquid nitrogen and stored at $-18^{\circ} \mathrm{C}$ prior to further analysis.

\subsection{Extraction and determination of phenolic compounds}

For the analysis of phenolic compounds (anthocyanins, quercetin compounds and selected phenolics), frozen petals were ground to a fine powder with liquid nitrogen. A sample of $2 \mathrm{~g}$ was extracted with $3 \mathrm{~mL}$ methanol containing $3 \%(\mathrm{v} / \mathrm{v})$ $\mathrm{HCOOH}$ and $1 \%(\mathrm{w} / \mathrm{v})$ 2,6-di-tert-butyl-4-methylphenol (BHT) in an ultrasonic bath for one hour. After extraction, the treated samples were centrifuged for $7 \mathrm{~min}$ at $12,000 \mathrm{~g}_{\mathrm{n}}$. The supernatant was filtered through Chromafil AO-45/25 polyamide filter (Macherey-Nagel, Düren, Germany) and transferred to a vial prior to injection into the highperformance liquid chromatography (HPLC) system. The samples were analyzed using a Thermo Finnigan Surveyor HPLC system (Thermo Scientific, San Jose, CA) with a diode array detector at $280 \mathrm{~nm}$ (gallic acid, protocatechuic acid, catechin, $p$-coumaric acid), $350 \mathrm{~nm}$ (quercetins) and $530 \mathrm{~nm}$ (anthocyanins). A Phenomenex (Torrance, CA) HPLC column C18 $(150 \mathrm{~mm} \times 4.6 \mathrm{~mm}$, Gemini $3 \mu)$ protected with a Phenomenex Security guard column, operated at $25{ }^{\circ} \mathrm{C}$, was used. The injection volume was $20 \mu \mathrm{L}$ and the flow rate was

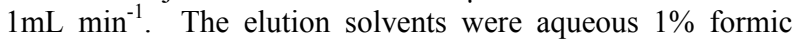
acid (A) and acetonitrile (B). The samples were eluted according to the linear gradient described by Marks et al. (2007): 0-5min, 3-9\% B; 5-15 min, 9-16\% B; 15-45min, 16$50 \% \mathrm{~B} ; 45-50 \mathrm{~min}, 50 \%$ isocratic; and finally washing and reconditioning of the column. The concentrations of selected phenolic compounds were assessed from peak areas and quantified with the use of corresponding external standards and anthocyanins by the use of calibration curve of cyanidin3,5-di-O-glucoside. Anthocyanins were further identified using a mass spectrometer (Thermo Scientific, LCQ Deca XP MAX, San Jose, USA) with an electroscopy interface (ESI) operating in positive ion mode from $\mathrm{m} / \mathrm{z} 115$ to 800 . The injection volume was $10 \mu \mathrm{L}$ and the flow rate maintained at $1 \mathrm{~mL} \min ^{-1}$. Capillary temperature was $250^{\circ} \mathrm{C}$, the sheath gas and auxiliary gas were 20 and 8 units respectively, the capillary voltage was $26 \mathrm{~V}$ and spray voltage $4 \mathrm{~V}$. Multipole $\mathrm{Rf}$ amplitude was $550 \mathrm{~V}_{\mathrm{p}-\mathrm{p}}$. All compounds were expressed as $\mu \mathrm{g} \mathrm{g}^{-1} \mathrm{FW}$.

\subsection{Chemicals}

The standards used to determine the phenolic compounds in samples were gallic acid, (+)-catechin, quercetin-3-Orutinoside, cyanidin-3,5-di-O-glucoside and cyanidin-3-Oglucoside from Sigma-Aldrich (Steinheim, Germany), catechin from Roth (Karlsruhe, Germany), protocatechulic acid from Merck (Darmdstadt, Germany), caffeic acid, $p$ coumaric acid, quercetin-3-O-glucoside, quercetin-3-Orhamnoside and peonidin-3-O-glucoside from Fluka (Buchs, Switzerland). The chemicals for the sample preparation and 
mobile phases were methanol, BHT and acetonitrile from Sigma-Aldrich and formic acid from Fluka. The water used in mobile phase was bidistilled and purified with a Milli-Q water purification system by Millipore (Bedford, MA).

\subsection{Statistical analysis}

Statistical analysis was conducted with the program Statgraphics Plus 4.0 (Statgraphics, Herndon, VA). One-way analysis of variance ANOVA was used for analysis of the effect of substrate $\mathrm{pH}$ level on the number of flowers per plant and concentration of anthocyanins, quercetins and selected phenolics in rose petals. Differences in phenolic concentrations among $\mathrm{pH}$ treatments were estimated with Duncan's multiple range test $(P<0.05)$.

\section{RESULTS}

\subsection{The number of flowers}

On the first sampling, miniature rose plants on average produced 9.25 flowers per plant with no significant differences observed among $\mathrm{pH}$ treatments. However, after 28 days, the number of flowers per plant was significantly affected by substrate $\mathrm{pH}$ level (Fig.1).
Compared to the first sampling, a decline in the number of flowers per plant was detected, when 'KORcrisett' rose was potted in both alkaline $(8.10 \%$ less flowers per plant) and acidic $\mathrm{pH}$ levels $(5.88 \%$ less flowers per

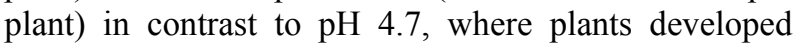
$40 \%$ more flowers, respectfully.

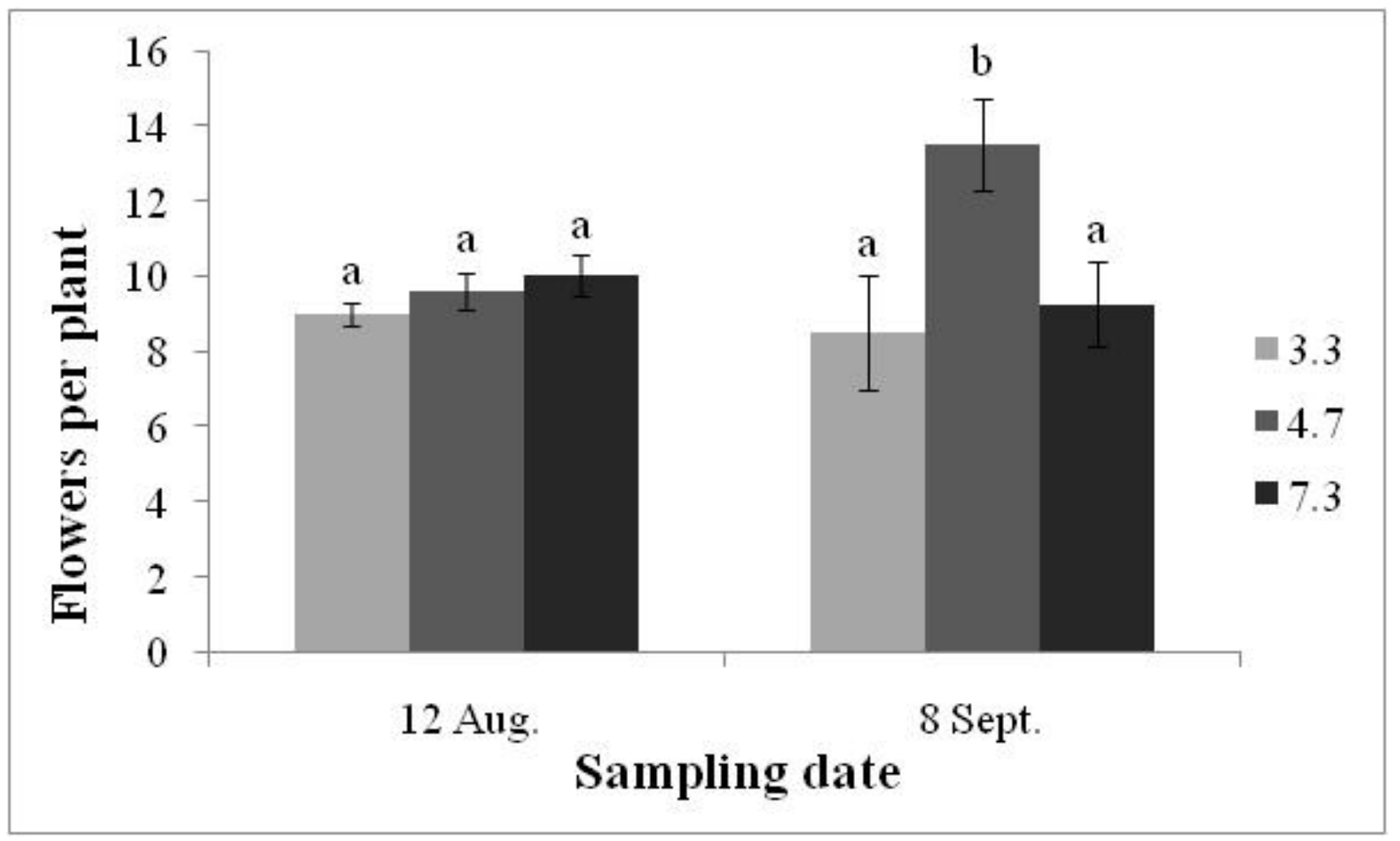

Figure 1: The effect of substrate $\mathrm{pH}$ on the number of flowers per plant at the beginning of the experiment (12 Aug.) and on day 28 (8 Sept.). Values carrying the same letters $(a, b)$ for each set of dates do not differ significantly by Duncan's multiple range test at $P<0.05$.

\subsection{Anthocyanins}

The HPLC chromatogram revealed five peaks at 530 $\mathrm{nm}$, corresponding to two pelargonidin-based, two cyanidin-based and one peonidin-based glucoside. On the first sampling, flower petals averagely contained
$283.79 \mu \mathrm{g} \mathrm{g}^{-1} \quad \mathrm{FW}$ pelargonidin-3,5-di-O-glucoside, $67.55 \mu \mathrm{g} \mathrm{g}^{-1} \mathrm{FW}$ cyanidin-3,5-di-O-glucoside, $20.94 \mu \mathrm{g}$ $\mathrm{g}^{-1} \mathrm{FW}$ pelargonidin-3-O-glucoside, $10.36 \mu \mathrm{g} \mathrm{g}^{-1} \mathrm{FW}$ cyanidin-3-O-glucoside, $9.87 \mu \mathrm{g} \mathrm{g}^{-1} \mathrm{FW}$ peonidin-3-Oglucoside and $380.80 \mu \mathrm{g} \mathrm{g}^{-1} \mathrm{FW}$ total anthocyanins, with 
no statistical differences observed among $\mathrm{pH}$ treatments (Table 1). After 28 days, significant differences among $\mathrm{pH}$ treatments were detected in the concentrations of all anthocyanins with the lowest values obtained from plants potted in $4.7 \mathrm{pH}$ level. The concentration of two major anthocyanins (pelargonidin-3,5-di-O-glucoside and cyanidin-3,5-di-O-glucoside) was $64.20 \%$ and $70.01 \%$ higher in the acidic $\mathrm{pH}$ level and $67.31 \%$ to $60.12 \%$ higher in alkaline $\mathrm{pH}$ level when compared to $4.7 \mathrm{pH}$ level. However, the greatest difference was observed in the concentration of pelargonidin-3-Oglucoside; in both acidic and alkaline $\mathrm{pH}$ levels a more than two fold increase was measured when compared to $\mathrm{pH}$ level 4.7. Total anthocyanins were $60.88 \%$ and $66.73 \%$ higher in alkaline and acidic $\mathrm{pH}$ levels compared to $\mathrm{pH}$ level 4.7 on the second sampling.
Generally, no statistical differences in single and total anthocyanins were detected between acidic and alkaline $\mathrm{pH}$ levels, except in the concentrations of cyanindin-3O-glucoside and peonidin-3-O-glucoside, where higher concentrations were detected in alkaline $\mathrm{pH}$ levels. Interestingly, the concentration of cyanidin-3,5-di-Oglucoside in petals of plants potted in acidic and alkaline $\mathrm{pH}$ level on the second sampling was more than threefold higher than on the first and consequently, the concentration of total anthocyanins in these treatments also increased $66.73 \%$ to $60.88 \%$. The concentration of the major anthocyanin (pelargonidin-3,5-di-Oglucoside) and three minor ones, however, were similar to those measured on the first sampling.

Table 1: Effect of substrate $\mathrm{pH}$ level on the concentration of anthocyanins $\left(\mu \mathrm{g} \mathrm{g}^{-1} \mathrm{FW}\right)$ in petals of Rosa $\times$ hybrida L. 'KORcrisett' on two sampling dates.

Anthocyanin $^{1}\left[\operatorname{mean} \pm \mathrm{SE}\left(\mu \mathrm{g} \mathrm{g}^{-1}\right)\right]$

\begin{tabular}{|c|c|c|c|c|c|c|c|}
\hline $\begin{array}{c}\text { Sampling } \\
\text { date }\end{array}$ & $\begin{array}{c}\mathrm{pH} \\
\text { Level }\end{array}$ & Pel-di-glu & Cy-di-glu & Pel-glu & Cy-glu & Peo-glu & $\begin{array}{c}\text { Total } \\
\text { anthocyanins }\end{array}$ \\
\hline \multirow{3}{*}{12 Aug. } & 3.3 & $267.12 \pm 16.40 \mathrm{a}^{2}$ & $69.91 \pm 6.00 \mathrm{a}$ & $20.33 \pm 1.47 \mathrm{a}$ & $10.85 \pm 0.78 \mathrm{a}$ & $10.10 \pm 0.84 \mathrm{a}$ & $375.57 \pm 24.30 \mathrm{a}$ \\
\hline & 4.7 & $265.17 \pm 18.93 \mathrm{a}$ & $62.06 \pm 6.00 \mathrm{a}$ & $19.35 \pm 1.48 \mathrm{a}$ & $9.65 \pm 0.70 \mathrm{a}$ & $8.75 \pm 0.71 \mathrm{a}$ & $357.55 \pm 25.53 \mathrm{a}$ \\
\hline & 7.3 & $319.08 \pm 21.51 \mathrm{a}$ & $70.68 \pm 7.34 \mathrm{a}$ & $23.15 \pm 1.57 \mathrm{a}$ & $10.57 \pm 0.68 \mathrm{a}$ & $10.75 \pm 0.86 \mathrm{a}$ & $409.28 \pm 35.56 \mathrm{a}$ \\
\hline \multirow{3}{*}{8 Sept. } & 3.3 & $324.40 \pm 29.65 b$ & $268.33 \pm 22.39 b$ & $27.32 \pm 3.64 b$ & $10.24 \pm 1.67 \mathrm{ab}$ & $9.54 \pm 1.62 \mathrm{ab}$ & $636.04 \pm 52.42 \mathrm{~b}$ \\
\hline & 4.7 & $197.56 \pm 13.22 \mathrm{a}$ & $157.83 \pm 13.72 \mathrm{a}$ & $13.57 \pm 0.66 \mathrm{a}$ & $6.19 \pm 1.40 \mathrm{a}$ & $6.28 \pm 0.24 \mathrm{a}$ & $381.48 \pm 27.75 \mathrm{a}$ \\
\hline & 7.3 & $330.53 \pm 34.82 b$ & $253.19 \pm 31.60 \mathrm{~b}$ & $27.74 \pm 4.02 b$ & $13.65 \pm 2.34 \mathrm{~b}$ & $12.23 \pm 1.60 \mathrm{~b}$ & $613.74 \pm 69.50 \mathrm{~b}$ \\
\hline
\end{tabular}

\footnotetext{
1 Anthocyanin: Pel-di-glu, Pelargonidin-3,5-di-O-glucoside; Cy-di-glu, Cyanidin-3,5-di-O-glucoside; Pel-glu, Pelargonidin-3-O-glucoside; Cy-glu, Cyanidin-3-O-glucoside; Peo-glu, Peonidin-3-O glucoside.

2 Values carrying the same letters (a-b) for each set of dates do not differ significantly by Duncan's multiple range test at $P<0.05$.
}

\subsection{Quercetin compounds and catechin}

Three quercetin compounds were determined in the petals of Rosa $\times$ hybrida L. 'KORcrisett', the predominant quercetin-3-O-rhamnoside and two minor ones (quercetin-3-O-glucoside and quercetin-3-O-rutinoside). On the first sampling petals on average contained $70.87 \mu \mathrm{g} \mathrm{g}^{-1} \mathrm{FW}$ quercetin-3-O-rhamnoside, $21.81 \mu \mathrm{g} \mathrm{g}^{-1} \mathrm{FW}$ quercetin-3-Oglucoside and $7.33 \mu \mathrm{g} \mathrm{g}^{-1} \mathrm{FW}$ quercetin-3-O-rutinoside, with no statistical differences observed among $\mathrm{pH}$ treatments (Table 2). On the second sampling, however, the lowest values of major and minor quercetin compounds were obtained from petals of plants, potted in a $4.7 \mathrm{ph}$ level. Statistically significant differences in the concentration of the two most abundant quercetin compounds were also detected between acidic and alkaline $\mathrm{pH}$ levels; the concentration of quercetin-3-O-rhamnoside was from $98.31 \%$ to $55.77 \%$ higher and quercetin-3-O-glucoside from $123.37 \%$ to $70.41 \%$ higher than in $\mathrm{pH}$ level 4.7. Compared to the first sampling, the concentration of all quercetin compounds in petals was higher on the second sampling in both acidic and alkaline $\mathrm{pH}$ levels but lower in $4.7 \mathrm{pH}$ level. The concentration of the predominant quercetin compound increased $61.72 \%$ and $59.28 \%$ in acidic and alkaline pH treatments and decreased by $25.95 \%$ in $\mathrm{pH}$ level 4.7 and a similar trend was detected for quercetin-3-O-rutinoside. The average concentration of catechin in petals of rose 'KORcrisett' on the first sampling was $2006.66 \mu \mathrm{g} \mathrm{g}^{-1} \mathrm{FW}$ and after 28 days, the concentration only increased in the petals of plants potted in an acidic pH level. Compared to the first sampling the concentration was $20.50 \%$ higher in $\mathrm{pH}$ level 3.3 and from $8.05 \%$ to $14.51 \%$ lower in $\mathrm{pH}$ levels 4.7 and 7.3 . 
Table 2: Effect of substrate $\mathrm{pH}$ level on the concentration of quercetin compounds and catechin $\left(\mu \mathrm{g} \mathrm{g}{ }^{-1} \mathrm{FW}\right)$ in petals of Rosa $\times$ hybrida L. 'KORcrisett' on two sampling dates.

$$
\text { Quercetin compounds }{ }^{1} \text { and catechin }\left[\text { mean } \pm \operatorname{SE}\left(\mu \mathrm{g} \mathrm{g}^{-1}\right)\right]
$$

\begin{tabular}{cccccc}
$\begin{array}{c}\text { Sampling } \\
\text { date }\end{array}$ & $\begin{array}{c}\mathrm{pH} \\
\text { Level }\end{array}$ & Q-rhamn & Q-glu & Q-rut & Catechin \\
\hline & 3.3 & $75.28 \pm 6.65 \mathrm{a}^{2}$ & $19.64 \pm 1.23 \mathrm{a}$ & $6.32 \pm 0.57 \mathrm{a}$ & $1936.52 \pm 103.86 \mathrm{a}$ \\
12 Aug. & 4.7 & $77.30 \pm 7.14 \mathrm{a}$ & $23.42 \pm 1.54 \mathrm{a}$ & $7.64 \pm 0.60 \mathrm{a}$ & $1973.64 \pm 72.32 \mathrm{a}$ \\
& 7.3 & $60.04 \pm 6.54 \mathrm{a}$ & $22.38 \pm 1.62 \mathrm{a}$ & $8.02 \pm 0.54 \mathrm{a}$ & $2109.81 \pm 82.28 \mathrm{a}$ \\
& 3.3 & $121.74 \pm 9.45 \mathrm{c}$ & $30.20 \pm 1.54 \mathrm{c}$ & $13.89 \pm 1.52 \mathrm{~b}$ & $2333.64 \pm 179.42 \mathrm{~b}$ \\
8 Sept. & 4.7 & $61.39 \pm 3.94 \mathrm{a}$ & $13.52 \pm 0.86 \mathrm{a}$ & $6.08 \pm 0.82 \mathrm{a}$ & $1826.65 \pm 105.03 \mathrm{a}$ \\
& 7.3 & $95.63 \pm 7.65 \mathrm{~b}$ & $23.04 \pm 2.32 \mathrm{~b}$ & $12.76 \pm 1.27 \mathrm{~b}$ & $1842.47 \pm 148.71 \mathrm{a}$
\end{tabular}

1 Quercetin compounds: Q-rhamn, Quercetin-3-O-rhamnoside; Q-glu, Quercetin-3-O-glucoside; Q-rut, Quercetin-3O-rutinoside.

2 Values carrying the same letters $(a, b, c)$ for each set of dates do not differ significantly by Duncan's multiple range test at $P<0.05$.

\subsection{Phenolic acids}

Four phenolic acids were extracted from the petals of miniature rose 'KORcrisett': gallic acid, protocatechulic acid, caffeic acid and $p$-coumaric acid (Table 3). On the first sampling rose petals averagely contained $31.37 \mu \mathrm{g}$ $\mathrm{g}^{-1} \mathrm{FW}$ gallic acid, $121.65 \mu \mathrm{g} \mathrm{g}^{-1} \mathrm{FW}$ protocatechulic acid, $133.56 \mu \mathrm{g} \mathrm{g}^{-1} \mathrm{FW}$ caffeic acid and $52.57 \mu \mathrm{g} \mathrm{g}^{-1} \mathrm{FW}$ p-coumaric acid. After 28 days, the lowest concentrations of all phenolic acids were detected in the petals of plants potted in $\mathrm{pH} 4.7$ and the highest in $\mathrm{pH}$ 3.3. The concentration of gallic acid was considerably lower on the second sampling; the decrease was more than seven fold in $\mathrm{pH}$ level 4.7, four fold in $\mathrm{pH}$ level 7.3 and more than two fold in $\mathrm{pH}$ level 3.3. Similarly, the concentrations of protocatechulic acid, caffeic acid and $p$-coumaric acid were significantly lower on the second sampling in both pH levels 4.7 and 7.3 and remained constant or even increased in the acidic $\mathrm{pH}$ level.

Table 3: Effect of substrate $\mathrm{pH}$ level on the concentration of phenolic acids $\left(\mu \mathrm{g} \mathrm{g}{ }^{-1} \mathrm{FW}\right)$ in petals of Rosa $\times$ hybrida L. 'KORcrisett' on two sampling dates.

Phenolic acid $\left[\right.$ mean $\left.\pm \operatorname{SE}\left(\mu g^{-1}\right)\right]$

\begin{tabular}{cccccc}
$\begin{array}{c}\text { Sampling } \\
\text { date }\end{array}$ & $\begin{array}{c}\text { pH } \\
\text { Level }\end{array}$ & Gallic acid & $\begin{array}{c}\text { Protocatehulic } \\
\text { acid }\end{array}$ & Caffeic acid & $\begin{array}{c}p \text {-Coumaric } \\
\text { acid }\end{array}$ \\
\hline \multirow{2}{*}{ 12 Aug. } & 3.3 & $27.24 \pm 2.02 \mathrm{a}^{1}$ & $104.42 \pm 9.11 \mathrm{a}$ & $123.34 \pm 6.51 \mathrm{a}$ & $48.04 \pm 3.60 \mathrm{a}$ \\
& 7.3 & $33.82 \pm 2.17 \mathrm{a}$ & $129.34 \pm 10.08 \mathrm{a}$ & $139.70 \pm 4.28 \mathrm{a}$ & $57.09 \pm 3.42 \mathrm{a}$ \\
& 3.3 & $11.28 \pm 2.03 \mathrm{~b}$ & $104.62 \pm 15.07 \mathrm{~b}$ & $118.79 \pm 16.0 \mathrm{~b}$ & $66.43 \pm 7.90 \mathrm{~b}$ \\
8 Sept. & 4.7 & $4.39 \pm 0.64 \mathrm{a}$ & $59.83 \pm 3.78 \mathrm{a}$ & $81.29 \pm 5.62 \mathrm{a}$ & $35.82 \pm 3.91 \mathrm{a}$ \\
& 7.3 & $7.82 \pm 1.17 \mathrm{ab}$ & $69.01 \pm 9.90 \mathrm{a}$ & $82.27 \pm 10.78 \mathrm{a}$ & $46.36 \pm 4.41 \mathrm{a}$ \\
\hline
\end{tabular}

1 Values carrying the same letters (a-b) for each set of dates do not differ significantly by Duncan's multiple range test at $P<0.05$. 


\section{DISCUSSION}

Overall, $\mathrm{pH}$ of the substrate had a significant effect on the number of flowers per plant as well as on the phenolic concentration in rose petals, as it affects nutrient uptake into plants (Smith et al., 2004a, Papafotiou et al., 2007) and consequently, reproductive efficiency. Similarly, the production of flowers in Senecio vulgaris L. was fewer in plants, grown in a nutrient deficient substrate (Brown and Molyneux, 1996) and acidic and alkaline $\mathrm{pH}$ levels caused significant changes in flowering of tobacco plants (Pasqua et al., 1991). Miniature rose plants developed significantly less flowers when grown in a substrate with $\mathrm{pH}$ levels 3.3 and 7.3 compared to $\mathrm{pH}$ level 4.7. As early as 1930, a lower substrate $\mathrm{pH}$ level (an average of 5.7 is mentioned as optimal) was reported to have a positive effect on the growth of different rose cultivars (Zieslin and Snir, 1989). A clear increase in flower production was also noted when rose plants were grown in a peat and Lelite substrate amended with ammonium. Yields per $\mathrm{ft}^{2}$ of roses increased as the proportion of $\mathrm{NH}_{4}{ }^{+}$to $\mathrm{NO}_{3}{ }^{-}$increased causing a decrease in $\mathrm{pH}$ of the rhizosphere (White ad Richter, 1973; Findenegg et al., 1986).

In contrast, the concentration of major and minor anthocyanins in rose petals increased in more acidic and alkaline pH levels. External stressors, such as substrate $\mathrm{pH}$ level, promote anthocyanin synthesis as was demonstrated by Hawrylak-Nowak (2008) who reported an increase in anthocyanin concentration dependant on substrate alkalinity in maize (Zea mays L.). Pelargonidin-3,5-di-O-glucoside and cyanidin-3,5-di-Oglucoside were the prevailing anthocyanic pigments in 'KORcrisett' petals, which is in accordance with the results of Biolley et al. (1994) and Mikanagi et al. (1995) who obtained similar results in other rose cultivars. Similarly to the research of Mikanagi et al. (1995) Rosa $\times$ hybrida L. 'KORcrisett' petals contained three minor anthocyanic pigments: pelargonidin-3-Oglucoside, cyanidin-3-O-glucoside and peonidin-3-Oglucoside, all significantly affected by substrate $\mathrm{pH}$ level. Quercetin-3-O-glucoside, quercetin-3-Orhamnoside and quercetin-3-O-rutinoside are the major quercetin compounds in rose flowers (Mikanagi et al., 1995; Cai et al., 2005) and, like anthocyanins, their concentration was lowest in flowers of the plants, potted in $4.7 \mathrm{pH}$ level. Among the phenolic acids gallic, protocatechuic acid, caffeic acid and $p$-coumaric acid were previously reported by Cai et al. (2005) and Kumar et al. (2008) in other rose cultivars and were significantly affected by $\mathrm{pH}$ level. According to our research, the optimal $\mathrm{pH}$ level of the substrate for increased flowering of miniature rose 'KORcrisett' was 4.7, however when an increase in phenolic concentration is preferential a modified $\mathrm{pH}$ level could be used to produce plants with flowers, which contain more anthocyanins and other phenolic compounds.

\section{ACKNOWLEDGEMENT}

This work is part of program Horticulture No. P4-00130481, funded by the Slovenian Research Agency (ARRS).

\section{REFERENCES}

Biolley, J.P., Jay, M., Viricel M.-R. (1994): Flavonoid diversity and metabolism in 100 Rosa x hybrida cultivars. Phytochemistry, 35: 413-419.

Brown, M.S., Molyneux, R.J. (1996): Effects of water and mineral nutrient deficiencies on pyrrolizidine alkaloid content of Senecio vulgaris flowers. Journal of the Science of Food and Agriculture, 70: 209-211.

Cai, Y.-Z., Xing, J., Sun, M., Zhan, Z.-Q., Corke, H. (2005): Phenolic antioxidants (hydrolyzable tannins, flavonols, and anthocyanins) identified by LC-ESI-MS and MALDI-QIT-TOF MS from Rosa chinensis flowers. Journal of Agricultural and Food Chemistry, 53: 9940-9948.

Cominelli, E., Gusmaroli, G., Allegra, D., Galbiati, M., Wade, H.K., Jenkins, G.I., Tonelli, C. (2007): Expression analysis of anthocyanin regulatory genes in response to different light qualities in Arabidopsis thaliana. Journal of Plant Physiology, 165: 886-894.

Dela, G., Or, E., Ovadia, R., Nissim-Levi, A., Weiss, D., Oren-Shamir, M. (2003): Changes in anthocyanin concentration and composition in 'Jaguar' rose flowers due to transient high-temperature conditions. Plant Science, 164: 333-340.

Eugster, C.H., Markifischer, E. (1991): The chemistry of rose pigments. Angewandte Chemie: International Edition in English, 30: 654-672.

Findenegg, G.R., van Beusichem, M.L., Keltjens, W.G. (1986): Proton balance of plants: physiological, agronomical and economical implications. Netherlands Journal of Agricultural Science, 34: 371-379. 
Harbage, J.F., Stimart, D.P., Auer, C. (1998): pH affects 1Hindole-3-butryric acid uptake but not metabolism during the initiation phase of adventitious root induction in apple microcuttings. Journal of the American Society for Horticultural Science, 123: 6-10.

Hawrylak-Nowak, B. (2008): Changes in anthocyanin content as indicator of maize sensitivity to selenium. Journal of Plant Nutrition, 31: 1232-1242.

Hughes, N.M., Morley, C.B., Smith, W.K. (2007): Coordination of anthocyanin decline and photosynthetic maturation in juvenile leaves of three deciduous tree species. New Phytologist, 175: 675-685.

Juszczuk, I.M., Wiktorowska, A., Malusa, E., Rychter, A.M. (2004): Changes in the concentration of phenolic compounds and exudation induced by phosphate deficiency in bean plants (Phaseolus vulgaris L.). Plant and Soil, 67: 41-49.

Kumar, N., Bhandari, P., Singh, B., Gupta, A.P., Kaul, V.K. (2008): Reversed phase-HPLC for rapid determination of polyphenols in flowers of rose species. Journal of Separation Science, 31: 262-267.

Marks, S.C., Mullen, W., Crozier, A. (2007): Flavonoid and chlorogenic acid profiles of English cider apples. Journal of Science of Food and Agriculture, 87: 719-728.

Mikanagi, Y., Yokoi, M., Ueda, Y., Saito, N. (1995): Flower flavonol and anthocyanin distribution in subgenus Rosa. Biochemical Systematics and Ecology, 23: 183-200.

Muller, R., Andersen, A.S., Serek, M. (1998): Differences in display life of miniature potted roses (Rosa hybrida L.). Scientia Horticulturae, 76: 59-71.

Papafotiou, M., Avajiannelli, B., Michos, C., Chatzipavlidis, I. (2007): Coloration, anthocyanin concentration, and growth of croton (Codiaeum variegatum L.) as affected by cotton gin trash compost use in the potting medium. Hortscience, 42: 83-87.

Pasqua, G., Monacelli, B., Altamura, M.M. (1991): Influence of $\mathrm{pH}$ on flower and vegetative bud initiation and development invitro. Cytobiosistematics, 68: 111-121.

Schmitzer, V., Osterc, G., Veberic, R., Stampar, F. (2009a): Correlation between chromaticity values and major anthocyanins in seven Acer palmatum Thunb. cultivars. Scientia Horticulturae, 119: 442-446.

Schmitzer, V., Veberic, G., Osterc, G., Stampar, F. (2009b): Changes in the phenolic concentration during flower development of rose 'KORcrisett'. Journal of the American Society for Horticultural Science, 134: 491-496.

Smith, B.R., Fischer, P.R., Argo, W.R. (2004a): Growth and pigment content of container-grown Impatiens and Petunia in relation to root substrate $\mathrm{pH}$ and applied micronutrient concentration. Hortscience, 39: 1421-1425.

Smith, B.R., Fischer, P.R., Argo W.R. (2004b): Nutrient uptake in container-grown Impatiens and Petunia in response to root substrate $\mathrm{pH}$ and applied micronutrient concentration. Hortscience, 39: 1426-1431.

White, J.W., Richter, D. (1973): Supplementary fluorescent lighting and low moisture stress improve growth of greenhouse roses. Journal of the American Society for Horticultural Science, 98: 605-607.

Zieslin, N., Snir, P. (1989): Responses of rose plants cultivar 'Sonia' and Rosa indica major to changes in $\mathrm{pH}$ and aeration of the root environment in hydroponic culture. Scientia Horticulturae, 37: 339-349. 